\title{
A meta-analysis of the effect of organic and mineral fertilizers on soil microbial diversity
}

\author{
Daniel P. Bebber ${ }^{1} \&$ Victoria R. Richards \\ ${ }^{1}$ Department of Biosciences, College of Life and Environmental Sciences, Geoffrey Pope Building, \\ University of Exeter, Stocker Road, Exeter, EX4 4QD, UK. \\ Author for correspondence: Daniel P. Bebber (d.bebber@exeter.ac.uk)
}

6

\section{ABSTRACT}

The Green Revolution of agriculture was in part driven by application of synthetic mineral fertilizers, largely supplanting organic manure as a source of the major nutrients nitrogen, phosphorous and potassium (NPK). Though enhancing crop production and global food security, fertilizers have contributed to soil acidification, eutrophication of water bodies, and greenhouse gas emissions. Organic agriculture, employing manures or composts, has been proposed as a way of mitigating these undesirable effects. Of particular interest is the effect of fertilizer regime on soil microbes, which are key to nutrient cycling, plant health and soil structure. Meta-analyses of experimental studies indicate that mineral fertilizer increases soil microbial biomass over unfertilized controls, and that organic fertilizers increase microbial biomass and activity over mineral fertilizers. However, the effect of fertilizers on soil microbial diversity remains poorly understood. Since biological diversity is an important determinant of ecosystem function and a fundamental metric in community ecology, the effects of fertilizer regimes on soil microbial diversity are of theoretical and applied interest. Here, we conduct a meta-analysis of 31 studies reporting microbial diversity metrics in mineral fertilized (NPK), organically fertilized (ORG) and unfertilized control (CON) soils. Of these studies, 26 reported taxonomic diversity derived from sequencing, gradient gel electrophoresis, RFLP, or dilution plate assay. Functional diversity, derived from Biolog Ecoplate $^{\mathrm{TM}}$ measures of carbon substrate metabolism, was reported in 8 studies, with 3 studies reporting both diversity metrics. We found that functional diversity was on average $2.6 \%$ greater in NPK compared with CON, $6.8 \%$ greater in ORG vs CON and $3.6 \%$ greater in ORG vs NPK. Prokaryote taxonomic diversity was not significantly different between NPK and CON, $4.2 \%$ greater in ORG vs CON and $4.6 \%$ greater in ORG vs. NPK. Fungal taxonomic diversity was not significantly different between NPK or ORG vs CON, but $5.4 \%$ lower between ORG and NPK. There was very high residual heterogeneity in all meta-analyses of soil diversity, suggesting that a large amount of further research with detailed analysis of soil properties is required to fully understand the influence of fertilizer regimes on microbial diversity and ecosystem function. 


\section{INTRODUCTION}

35 Diversity plays a key role in the resilience and adaptability of complex systems (Page, 2011), and biological diversity has been central to understanding of the structure and function of ecological communities (Ricklefs \& Schluter, 1994). Human activities are rapidly eroding global biodiversity (Ceballos et al., 2015), hence understanding how human activities influence diversity and how negative impacts can be avoided is an important goal of applied ecology (Sutherland et al., 2006; Rudd et al., 2011). Recent advances in environmental DNA sequencing and metabarcoding have revealed enormous and unexpected microbial diversity in all habitats, particularly soils (Thompson et al., 2017; Lloyd et al., 2018). Given the fundamental importance of soils in terrestrial ecosystems, agriculture and food security, there is growing interest in the role of microbial diversity in processes such as nutrient cycling (Delgado-Baquerizo et al., 2016), and how soil diversity can be managed for maintenance of ecosystem services (Lemanceau et al., 2015). In agriculture, soil microbes are critical to desirable functions such as nutrient cycling, carbon storage, erosion control via soil aggregation, and disease suppression (Rillig et al., 2002; Mazzola, 2004; Sahu et al., 2017). A large fraction of the world's agriculture soils are in poor and deteriorating condition largely due to agricultural activities (Wuepper et al., 2020). Therefore, understanding how to manage soils for microbial diversity could help to prevent further deterioration.

Modern intensive, or conventional, agricultural methods, including application of mineral and chemical fertilisers, regular tillage, and use of synthetic pesticides and herbicides, aim to increase soil nutrition and suppress harmful species to produce higher crop yields, but these methods are environmentally damaging (Robertson, 2000). For example, growing pressure on agricultural land has resulted in soil nutrient depletion and soil erosion (Wopereis, Tamèlokpo, \& Ezui, 2006; Lal, 2009). Mineral fertilizers supply nitrogen $(\mathrm{N})$ as ammonium nitrate or urea, phosphorus $(\mathrm{P})$ and potassium $(\mathrm{K})$, with around 100 Tg N applied globally each year (FAO, 2020). The nitrogen sources are derived from the Haber-Bosch process which reduces dinitrogen to ammonia, accounting for around one third of the nitrogen fixed from the atmosphere (Fowler et al., 2013). Soil and plant-symbiotic microbes fix another third, marine cyanobacteria another third, with small contributions from lightning and fossil fuel combustion (Fowler et al., 2013). Typically less than half the $\mathrm{N}$ applied is taken up by crops, the remainder contributing to water pollution and the release of NOX greenhouse gases (Zhang et al., 2015). Organic agriculture, which applies manure- or compost-based fertilizers and soil conditioners and does not employ chemical pest controls (with certain exceptions), has been proposed as a means of both increasing soil nutrition and reducing environmental impacts (Reganold \& Wachter, 2016), but evidence for organic benefits remains equivocal. For example, eutrophication potential appears greater in many organic than conventional crop systems (Clark \& Tilman, 2017) communities, is linked to microbial diversity (Kibblewhite et al., 2008; van Bruggen et al., 2019). 
99

Microbial diversity is correlated with soil ecosystem multifunctionality including plant productivity, microbial biomass, availability of nitrate, ammonium and phosphorus, and nitrogen mineralisation rates (Delgado-Baquerizo et al., 2016). Hence, management to enhance soil microbial diversity could improve soil health. Soils are exceedingly complex and biologically-diverse ecosystems, varying in physico-chemical and biological composition across spatial scales (Howe et al., 2014; Thompson et al., 2017). Meta-analyses of multiple individual studies can reveal general trends and patterns in this complexity and determine the effects of management interventions. For example, observational data suggest that biological richness (measured by DNA sequences) is greatest at neutral $\mathrm{pH}$ and at a mean temperature of $10{ }^{\circ} \mathrm{C}$ (Thompson et al., 2017). Meta-analysis of experimental studies shows that $\mathrm{pH}$ has the greatest influence on soil microbial diversity among global change factors, alpha diversity rising with pH (Zhou et al., 2020). Nitrogen and NPK have negative or non-significant effects on alpha diversity depending on microbial group, with significant negative influences of $\mathrm{N}$ alone on diversity in agricultural soils. Soil functionality, defined as the range of biogeochemical processes carried out by soils, increases with N and NPK. Changes in diversity are negatively correlated with changes in functionality, perhaps due to functional redundancy (Zhou et al., 2020). Other meta-analyses have demonstrated that microbial diversity (Venter et al., 2016) and biomass (McDaniel et al., 2014) increase in crop rotations compared with monocultures. Organic agriculture greatly increases microbial biomass carbon, microbial biomass nitrogen, and enzymatic activity compared with conventional systems (Lori et al., 2017). Previously, a small meta-analysis found no significant effect of organic agriculture on soil organism diversity, but this only included five studies and occurred before widespread use of sequencing to soil microbial diversity (Bengtsson et al., 2005). However, despite growing application of sequencing technologies in microbial ecology, results on the effects of organic and mineral fertilizers on measures of soil microbial diversity remain unsynthesized.

Here, we conduct a meta-analysis quantifying the effects of organic fertilizers (manures and manure composts) and mineral fertilizers (NPK) on soil microbial diversity, in comparison with unfertilized controls. We compare results for taxonomic and functional diversity, and investigate the influence of factors such as soil chemistry and duration of organic treatment on these effects. We hypothesise that organic inputs will increase microbial diversity as compared to mineral fertilizer inputs, based on the observation that organic fertilizers increase microbial biomass and enzymatic activity compared with NPK (Lori et al., 2017). 


\section{MATERIALS AND METHODS}

We used meta-analysis to test for differences in soil microbial functional $\left(\mathrm{H}_{\text {fun }}\right)$ and taxonomic $\left(\mathrm{H}_{\mathrm{tax}}\right)$ diversity between soils treated with manure-based organic fertilizer (ORG), mineral fertilizer (NPK) and control $(\mathrm{CON})$. Here, $\mathrm{H}_{\mathrm{tax}}$ is defined as Shannon's diversity index calculated from the relative abundance of species, operational taxonomic units (OTUs) or amplicon sequence variants (ASVs; Callahan et al., 2017) in a sample. $\mathrm{H}_{\text {fun }}$ is defined as Shannon's diversity calculated from the relative conversion rates of various carbon sources in Biolog Ecoplates (e.g. Ros et al., 2006). We conducted a literature search using combinations of the terms 'soil', 'organic', 'agriculture', 'microbial', 'diversity', 'bacteria*', 'fung*', 'communit*', 'fertilizer', 'manure' and 'compost' (where * indicates a wildcard search, where appropriate) on Google Scholar, Scopus and Web of Science between August 2018 and June 2019. Additionally, the reference lists of the papers were browsed to find potentially appropriate studies which were not identified during the online literature search. All potentially appropriate papers identified for the meta-analysis came from peer-reviewed journals.

Papers were considered eligible for the analysis if they met the following criteria, adapted from Lori et al. (2017): Comparisons of the farming systems should be pairwise, meaning the organic- and mineralfertilised treatments were subject to the same climatic conditions before and during sampling; The organic treatment must have been applied for a minimum of two consecutive years prior to soil sampling, and the treatments must be defined by the study; Results must report the mean Shannon diversity index $(\mathrm{H})$ per treatment, uncertainty of the mean (either standard error of the mean or standard deviation of the sample distribution) and sample size (n); experiments were conducted in open fields or under cover, not in pots or containers; the study must have been published no earlier than the year 2000; the mineral and organic treatments must be clearly described (description of fertilizer, application rate). If there were several different organic or conventional treatments within the same study, all appropriate combinations were reported and treated as individual comparisons but with non-independent errors (see meta-analysis methods). Results of combination treatments (e.g. manure plus NPK fertilizer) were not included.

For all valid studies, we extracted mean, SE or SD, and sample size for $\mathrm{H}$, for control, NPK and organic treatments. Where SE was reported, this was converted to SD by multiplying by the square root of sample size. When data were presented in graphical form, we extracted means and errors using the online tool WebPlotDigitalizer (https://automeris.io/WebPlotDigitizer/). Additionally we abstracted the following variables: study location; reported soil type, duration of organic treatment, organic treatment type (i.e. source of manure), organic treatment application rate (mass per hectare per year or equivalent nitrogen mass per hectare per year); mineral fertilizer application rate (nitrogen mass per hectare per 
sampled (usually the mid-point of the range of depths sampled); brief summary of the methodology used (e.g. 16S sequencing, 16S DGGE, Biolog Ecoplate). Where reported we abstracted mean and SE of soil $\mathrm{pH}$; and mean and $\mathrm{SE}$ of soil nitrogen content $\left(\mathrm{mg} \mathrm{kg}^{-1}\right)$.

\section{Meta-analysis}

Meta-analysis was conducted using the metafor package v. 2.4-0 for R v. 4.0.2 (Viechtbauer, 2010). Effect size was calculated as the log-transformed ratio of means (Hedges et al., 1999). There was at least one pairwise comparison of $\mathrm{H}$ in each study. However, several studies reported data from more than one pairwise comparison, with multiple organic and/or conventional fertilisation treatments investigated. We fitted multi-level random- and mixed-effects (i.e. testing for the effects of moderator variables) models by restricted maximum likelihood, with random intercepts per study. Other similar meta-analyses have ignored potential non-independence among results from the same study and treated each reported mean as an independent replicate (Lori et al., 2017). Standard errors and confidence limits for parameters were estimated from the $t$-distribution. We report the $I^{2}$ statistic and $Q$-test for heterogeneity (Higgins \& Thompson, 2002), and provide funnel plots rank correlation tests for funnel plot asymmetry (Viechtbauer, 2010).

\section{RESULTS}

We abstracted data from 31 studies which met our requirements (Table S1). Our search criteria provided a long-list of 259 studies, of which 195 were rejected on the basis of the abstract, leaving a shortlist of 64. A further 33 were rejected after detailed reading of the full text. Around half (16) of the included studies reported one set of comparisons, with either or both of unfertilized control $(\mathrm{CON})$ and mineral fertilizer (NPK), 10 reported two comparisons, and five studies reported up to six comparisons, giving 57 comparisons in total. The majority of treatments were replicated three or four times. Bacteria were the most commonly analysed group (24 studies, including one of actinomycetes only, one of bacteria and archaea, and one of nitrogen-fixing bacteria), followed by fungi (6 studies, including one of arbuscular mycorrhizal fungi only). The functional diversity studies, and the single study reporting soil dilution plate assays (Mahanta et al., 2017), were taxonomically non-specific. Most studies were conducted in China (19), followed by India (6), with single studies from Austria, Canada, Denmark, Kenya, the Netherlands, and the USA.

Soil types were not reported according to any standard taxonomy. Soils were sampled to a median depth of up to $15 \mathrm{~cm}$ (median $10.0 \mathrm{~cm}$, IQR $7.5-10.0 \mathrm{~cm}$ ). Soil nitrogen content in unfertilized plots was reported in 14 studies (mean $\mathrm{mg} \mathrm{N} \mathrm{kg}^{-1}$ median 77.9, IQR 28.5 - 99.6). Manure-based organic fertilizers were applied in all studies, derived variously from cattle, pigs, poultry, horses, sheep, or mixtures of these. Composted manures were employed in 8 studies, fresh manures in 24 studies (one study 
employed both). A small number of studies reported more than one manure treatment or level (Mahanta et al., 2017; Hu et al., 2018b; Liu et al., 2019). Application rates were reported as either total mass per area per year (24 studies, median $10 \mathrm{t} \mathrm{ha}^{-1} \mathrm{y}^{-1}$, IQR $\left.4.9-18.6 \mathrm{t} \mathrm{ha}^{-1} \mathrm{y}^{-1}\right)$ and/or as nitrogen addition (15 studies, median $102.0 \mathrm{~kg} \mathrm{ha}^{-1} \mathrm{y}^{-1}$, IQR 60.0 - $140.0 \mathrm{~kg} \mathrm{ha}^{-1} \mathrm{y}^{-1}$ ). We did not attempt to estimate nitrogen content in manures where this was not reported, due to the large variability in the nitrogen fraction among different treatments. The reported nitrogen fraction varied from $0.4 \%$ in horse manure to $2.7 \%$ in pig manure, with overall median $1.0 \%$ (IQR $0.7-2.0 \%$ ) among the treatments reported in the studies. The level of nitrogen in the manure treatment was similar to that in corresponding NPK fertilizer treatments, where reported (absolute percentage difference median 13.4\%, IQR 0.0 - $56.0 \%$ ). The duration of organic treatment was right-skewed, but many studies reported treatment periods of several decades (median 20 y, IQR $11-34.5 \mathrm{y}$ ). A variety of crops were grown, either as monocultures or in mixtures, the most common being maize ( 9 studies), wheat ( 7 studies), and rice (6 studies). Soil $\mathrm{pH}$ in unfertilized plots was reported in 16 studies (mean $\mathrm{pH}$ median 6.5, interquartile range 6.0 - 7.7). Meta-regression showed that soil $\mathrm{pH}$ declined under NPK treatment by $-0.53 \pm 0.20$ compared to control soil (Fig. S1a). Manure-based fertilizers increased $\mathrm{pH}$ in acid soils and reduced $\mathrm{pH}$ in alkaline soils (Fig. S1b). Funnel plots showed no asymmetry (Fig. S2). There was a large degree of residual heterogeneity in the meta-analyses of soil pH (Table S2).

$\mathrm{H}_{\text {fun }}$ was reported by 8 studies, all employing Biolog Ecoplates (Table $\mathrm{S} 1$ ). $\mathrm{H}_{\text {fun }}$ varied between 1.12 and 4.61 with values in three clusters comprising a single study from Austria with $\mathrm{H}_{\text {fun }} \sim 1.2$, four studies from China and one from India with $\mathrm{H}_{\text {fun }} \sim 2.9$, and two studies from India with $\mathrm{H}_{\text {fun }} \sim 4.5$ (Fig. 1a-c). $\mathrm{H}_{\text {fun }}$ increased by an average of $2.6 \%$ in NPK vs. CON, $6.8 \%$ in ORG vs. CON, and $3.6 \%$ in ORG vs. NPK (Fig. 2, Table 1). We found no influence of the duration of organic amendment on the change in $\mathrm{H}_{\text {fun }}$ compared with control (LRM change per year of organic treatment $-0.0008 \pm 0.0013 \mathrm{y}^{-1}, \mathrm{t}=-0.58$, $\mathrm{p}=0.56)$ or NPK $\left(0.0006 \pm 0.0007 \mathrm{y}^{-1}, \mathrm{t}=0.84, \mathrm{p}=0.40\right)$ treatments. We found no effect of the level of NPK addition relative to control $(-0.0013 \pm 0.0009, \mathrm{t}=-1.42, \mathrm{p}=0.15)$, nor of level of organic fertilizer addition quantity $(0.0000 \pm 0.0000, \mathrm{t}=-0.35, \mathrm{p}=0.72)$ or nitrogen equivalent relative to control $(0.0001 \pm 0.0005, \mathrm{t}=0.18, \mathrm{p}=0.86)$. We found a marginally-significant effect of control soil $\mathrm{pH}$ on the effect size of ORG vs. CON $(-0.052 \pm 0.025, \mathrm{t}=-2.10, \mathrm{p}=0.036)$, but not of soil $\mathrm{pH}$ on NPK vs. $\mathrm{CON}(0.0045 \pm 0.0527, \mathrm{t}=0.085, \mathrm{p}=0.93)$. Soil $\mathrm{N}$ did not influence the effect size of ORG vs. CON $(0.000 \pm 0.001, t=-0.01, p=0.99)$. Funnel plots did not exhibit significant asymmetry (Fig. S3). There was a large degree of residual heterogeneity in all meta-analyses of $\mathrm{H}_{\text {fun }}\left(\mathrm{I}^{2}>75 \%\right.$, Table $\left.\mathrm{S} 2\right)$.

$\mathrm{H}_{\mathrm{tax}}$ was reported in 31 studies, employing DNA amplicon sequencing (17 studies), various forms of gradient gel electrophoresis (11 studies), soil dilution plate assay (1 study) and T-RFLP (1 study). $\mathrm{H}_{\mathrm{tax}}$ tended to be higher in prokaryotes than fungi, and in sequencing compared with DGGE methods (Fig. 1d-f). Median $\mathrm{H}_{\text {tax }}$ for prokaryotes was 6.36 using sequencing and 2.85 using DGGE. Median $\mathrm{H}_{\text {tax }}$ for fungi was 3.36 using sequencing and 1.40 using DGGE. $\mathrm{H}_{\text {tax }}$ of NPK-fertilized soils did not differ from 
206

207

208

209

210

211

212

213

214

215

216

217

218

219

220

221

222

223

224

225

226

227

228

229

230

231

232

233

234

235

236

237

238

239

240

control for prokaryotes or fungi, nor in the single study using dilution plate assays (Fig. 3, Table 2). $\mathrm{H}_{\text {tax }}$ of prokaryotes was greater in ORG soils than both NPK-fertilized soils and control. Fungi were less taxonomically diverse in ORG than NPK, but there was no significant difference in fungal $\mathrm{H}_{\text {tax }}$ between ORG and CON. In the soil dilution plate assay, organically fertilized soils were more diverse than NPK or CON. We found no evidence that duration of organic amendments $(0.0006 \pm 0.0009, \mathrm{t}=0.66, \mathrm{p}=$ $0.51), \mathrm{pH}(-0.0054 \pm 0.0038, \mathrm{t}=-1.42, \mathrm{p}=0.15)$ or soil $\mathrm{N}(-0.0008 \pm 0.0004, \mathrm{t}=-2.1, \mathrm{p}=0.051)$ influenced the effect size of ORG vs. CON. Funnel plots did not exhibit significant asymmetry (Fig. S4). There was a large degree of residual heterogeneity in meta-analyses of $\mathrm{H}_{\operatorname{tax}}\left(\mathrm{I}^{2}>95 \%\right.$, Table $\left.\mathrm{S} 2\right)$.

\section{DISCUSSION}

We found significant, but varying, effects of both NPK and organic fertilizers on soil microbe taxonomic and functional diversity. Taxonomic diversity in organic treatments compared with NPK was greater for prokaryotes but lower for fungi, and was greater for organic treatments compared with control for prokaryotes with no significant difference in fungi. We found no significant difference in taxonomic diversity between NPK and control for either prokaryotes or microbes. Functional diversity was significantly greater in NPK compared with control, and in organic treatment compared with NPK. We did not detect any significant influence of factors such as duration or type of organic treatment, soil chemistry or experimental methodology on effect sizes. Importantly, the residual heterogeneity in all meta-analyses was very high.

Several factors must be considered when interpreting the effects of fertilizers on soil microbial functional and taxonomic diversity (Fig. 4). First, while in many studies the amount of nitrogen applied in organic and NPK treatments was similar, farmyard manure is far more physically, chemically and biologically complex. In addition to NPK, manures contain undigested plant matter (lignin, cellulose, hemicellulose), lipids, carbohydrates, proteins, and nutritive elements (e.g. magnesium, iron, manganese, zinc, copper) (Levi-Minzi et al., 1986). If structural complexity and heterogeneity are enhanced by the addition of organic matter across spatial scales (Lehmann et al., 2008), this could in itself increase microbial diversity through provision of ecospace that reduces interspecific competition (Vos et al., 2013). Provision of additional energy (organic carbon) and micronutrients in manures could sustain a greater diversity of microbes via the species-energy hypothesis which predicts that more species can be sustained in ecosystems supporting more individuals (Clarke \& Gaston, 2006), since manure increases soil microbial biomass more than NPK (Lori et al., 2017). Second, microbial communities may be indirectly influenced by changes in crop plants. While organic agriculture tends to be less productive in terms of crop yields (de Ponti et al., 2012; Hijbeek et al., 2017), there is some evidence that root development is greater in organic farming (Hu et al., 2018a). Plant rhizospheres tend to harbour the greatest microbial diversity of all terrestrial ecosystems (Thompson et al., 2017), hence 
241 it is possible that enhanced root development and exudation of organic compounds influence the soil 242 diversity measured in these studies. Third, there is the gut microbial community residing within the manure itself. Both fresh and composted manures have high fungal and prokaryote diversity, with community composition changing as composting proceeds (Meng et al., 2019). Bacterial diversity has been found to peak during the thermophilic phase of aerobic composting during which temperatures exceeded $55^{\circ} \mathrm{C}$, while fungal diversity was lowest during this stage (Meng et al., 2019). Composting can reduce the presence of undesirable microbes in manure, for example those carrying antimicrobial resistance genes (Gou et al., 2018), but gut microbes (including human pathogens) can survive for long periods in compost-amended soils (Sharma \& Reynnells, 2016). Hence, increased soil microbial diversity in organic systems may be due to persistence of gut microbes.

Few studies reported both taxonomic and functional diversity, hence we were unable to determine a relationship between these two metrics. Functional diversity has been found to increase with species diversity in plant communities (Mensah et al., 2016; Zhang et al., 2017), but less clearly in bird communities (Morelli et al., 2018). The relationship between soil taxonomic diversity and ecosystem function (as opposed to functional diversity) tends to be positive (Philippot et al., 2013; Bardgett \& Putten, 2014; Maron et al., 2018). Given that ecosystem functions like nitrogen cycling require multiple interacting processes, a positive relationship between taxonomic diversity and functional diversity might be expected. Soil ecosystem multifunctionality (the capacity of soils to sustain many functions simultaneously) increases with microbial diversity (Delgado-Baquerizo et al., 2016), while taxonomic and functional gene diversity are closely correlated (Zhang et al., 2019). However, taxonomic and functional diversity can be decoupled by the process of horizontal gene transfer, because different taxa can perform similar tasks through shared genes (Zhang et al., 2019). In addition, the presence of physiologically-distinct subgroups within OTUs commonly defined by $>97 \%$ sequence similarity (socalled 'microdiversity') means that functional diversity can be large in groups of apparently identical microbial taxa (Larkin \& Martiny, 2017). Microbial functional diversity tends to be considered from the perspective of potential functions inferred from gene sequences (Escalas et al., 2019). In contrast, we report results from studies of the diversity of actual functions (metabolization of carbon sources) carried out by the soil microbial community. These genotypic vs. phenotypic measures of functional diversity are analogous to the fundamental and realized niches of species, whereby the potential functions identified in gene sequences are likely to exceed the observed functions carried out by the community under particular environmental conditions (Escalas et al., 2019). Discovering the relationships between potential and observed functions of microbial communities is a key goal of microbial ecology.

274 Organic farming has been promoted as a more sustainable alternative to conventional agriculture, because of greater energy efficiency, potentially closed nutrient cycles and increased biodiversity 
276 (Reganold \& Wachter, 2016). Certainly, the rapid decline of insect populations around the world due 277 to intensive agriculture and pesticides, is an urgent impetus for reconsidering the way we produce food 278 (Sánchez-Bayo \& Wyckhuys, 2019). These potential benefits come at a cost of reduced productivity 279 compared with convential farming (de Ponti et al., 2012; Hijbeek et al., 2017), though there is some 280 evidence that organic production can eventually catch up with conventional yields and provides greater 281 spatial and temporal stability (Schrama et al., 2018). Environmental impacts of organic agriculture 282 include greater land use and eutrophication potential per unit of food produced, contradicting the aim 283 of closed nutrient cycles (Clark \& Tilman, 2017). Our results suggest that, when considering organic crop fertilization alone and as a strict alternative to NPK (rather than a mixed system of manure-derived and NPK fertilizer), microbial functional diversity and bacterial taxonomic diversity are slightly, but significantly greater in organic systems while fungal taxonomic diversity is slightly but significantly lower. The enhanced eutrophication potential of organic farming, due to temporal mismatching between fertilizer addition and plant demand, is much larger than the increases in taxonomic or functional diversity we found (Clark \& Tilman, 2017). Hence, it appears that increased soil microbial diversity under organic farming does not translate to improved nutrient cycling and retention. While we did not compare combined treatments (e.g. NPK with manure or compost) with single treatments, farmers commonly apply a diversity of fertilizers. For example, a comparison of low-input organic systems with conventional mixed (NPK and manure) and conventional NPK-fertilized systems in Switzerland found the greatest bacterial $\alpha$-diversity in the organic systems, followed by the mixed and NPK-only systems (Hartmann et al., 2015).

Many studies addressing soil microbial diversity in response to fertilization could not be included in our meta-analysis because of incomplete or unclear reporting. Without giving specific examples, we found that many studies did not provide uncertainties (standard error or standard deviation) for parameter estimates, gave unclear descriptions of the fertilisation routines and inputs, or reported alternative measures of diversity. Of the studies we included, several did not report basic soil chemistry metrics such as $\mathrm{pH}$ and nitrogen content. Given the importance of $\mathrm{pH}$ in determining soil microbial

302 diversity (Zhou et al., 2020), and the central relevance of nitrogen in these experiments, any future research should report these variables at minimum. We were only able to include a small number of studies in our meta-analysis, which revealed very large residual heterogeneity among effect sizes, i.e. most of the variation in effect sizes among studies remains unexplained. Further research will reveal whether the mean effects we detected are general, and what other factors help explain variation among soils, climates, locations and experimental treatments. To achieve this, it is critical that detailed and complete data on key variables are reported. In addition, better understanding of soil ecosystem functioning will be achieved via analysis of the taxa and functional genes identified within samples, in addition to summary metrics like diversity (Hartmann et al., 2015). In this way, the powerful new 
bioRxiv preprint doi: https://doi.org/10.1101/2020.10.04.325373; this version posted October 8, 2020. The copyright holder for this preprint (which was not certified by peer review) is the author/funder, who has granted bioRxiv a license to display the preprint in perpetuity. It is made available under aCC-BY-NC-ND 4.0 International license.

Fertilizer effects on soil microbial diversity

311 bioinformatics tools at our disposal can be harnessed to fully understand the relationships between

312 agriculture and soil health.

\section{DATA AVAILABILITY}

314 The data used in the meta-analysis will be made available on publication of the manuscript.

AUTHORS CONTRIBUTIONS

DB developed the research. DB and VR collected data, analysed results and wrote the paper.

FUNDING

VR was funded by an undergraduate project studentship at Exeter University, UK. DB was funded by

EC Horizon 2020 project ID 727624.

\section{REFERENCES}

Balachandar, D., Doud, M.S., Schneper, L., Mills, D. \& Mathee, K. (2014) Long-Term Organic Nutrient Management Fosters the Eubacterial Community Diversity in the Indian Semi-arid Alfisol as Revealed by Length Heterogeneity-PCR. Communications in Soil Science and Plant Analysis, 45, 189-203.

Bardgett, R.D. \& Putten, W.H. van der (2014) Belowground biodiversity and ecosystem functioning. Nature, 515, 505.

Bengtsson, J., AhnströM, J. \& Weibull, A.-C. (2005) The effects of organic agriculture on biodiversity and abundance: a meta-analysis: Organic agriculture, biodiversity and abundance. Journal of Applied Ecology, 42, 261-269.

van der Bom, F., Nunes, I., Raymond, N.S., Hansen, V., Bonnichsen, L., Magid, J., Nybroe, O. \& Jensen, L.S. (2018) Long-term fertilisation form, level and duration affect the diversity, structure and functioning of soil microbial communities in the field. Soil Biology and Biochemistry, 122, 91-103.

van Bruggen, A.H.C., Goss, E.M., Havelaar, A., van Diepeningen, A.D., Finckh, M.R. \& Morris, J.G., $\operatorname{Jr}(2019)$ One Health - Cycling of diverse microbial communities as a connecting force for soil, plant, animal, human and ecosystem health. Science of the Total Environment, 664, 927-937.

van Bruggen, A.H.C., Sharma, K., Kaku, E., Karfopoulos, S., Zelenev, V.V. \& Blok, W.J. (2015) Soil health indicators and Fusarium wilt suppression in organically and conventionally managed greenhouse soils. Applied Soil Ecology, 86, 192-201.

Callahan, B.J., McMurdie, P.J. \& Holmes, S.P. (2017) Exact sequence variants should replace operational taxonomic units in marker-gene data analysis. The ISME Journal, 11, 2639-2643.

Ceballos, G., Ehrlich, P.R., Barnosky, A.D., García, A., Pringle, R.M. \& Palmer, T.M. (2015) Accelerated modern human-induced species losses: Entering the sixth mass extinction. Science Advances, 1, e1400253.

Chaudhry, V., Rehman, A., Mishra, A., Chauhan, P.S. \& Nautiyal, C.S. (2012) Changes in Bacterial Community Structure of Agricultural Land Due to Long-Term Organic and Chemical Amendments. Microbial Ecology, 64, 450-460. 
Chen, C., Zhang, J., Lu, M., Qin, C., Chen, Y., Yang, L., Huang, Q., Wang, J., Shen, Z. \& Shen, Q. (2016) Microbial communities of an arable soil treated for 8 years with organic and inorganic fertilizers. Biology and Fertility of Soils, 52, 455-467.

Chen, X., Li, Z., Liu, M., Jiang, C. \& Che, Y. (2015) Microbial community and functional diversity associated with different aggregate fractions of a paddy soil fertilized with organic manure and/or NPK fertilizer for 20 years. Journal of Soils and Sediments, 15, 292-301.

Clark, M. \& Tilman, D. (2017) Comparative analysis of environmental impacts of agricultural production systems, agricultural input efficiency, and food choice. Environmental Research Letters, 12, 064016.

Clarke, A. \& Gaston, K.J. (2006) Climate, energy and diversity. Proceedings of the Royal Society B: Biological Sciences, 273, 2257-2266.

Cui, X., Zhang, Y., Gao, J., Peng, F. \& Gao, P. (2018) Long-term combined application of manure and chemical fertilizer sustained higher nutrient status and rhizospheric bacterial diversity in reddish paddy soil of Central South China. Scientific Reports, 8, 1-11.

Delgado-Baquerizo, M., Maestre, F.T., Reich, P.B., Jeffries, T.C., Gaitan, J.J., Encinar, D., Berdugo, M., Campbell, C.D. \& Singh, B.K. (2016) Microbial diversity drives multifunctionality in terrestrial ecosystems. Nature Communications, 7, 10541.

Ding, J., Jiang, X., Guan, D., Zhao, B., Ma, M., Zhou, B., Cao, F., Yang, X., Li, L. \& Li, J. (2017) Influence of inorganic fertilizer and organic manure application on fungal communities in a long-term field experiment of Chinese Mollisols. Applied Soil Ecology, 111, 114-122.

Ding, J., Jiang, X., Ma, M., Zhou, B., Guan, D., Zhao, B., Zhou, J., Cao, F., Li, L. \& Li, J. (2016) Effect of 35 years inorganic fertilizer and manure amendment on structure of bacterial and archaeal communities in black soil of northeast China. Applied Soil Ecology, 105, 187-195.

Escalas, A., Hale, L., Voordeckers, J.W., Yang, Y., Firestone, M.K., Alvarez-Cohen, L. \& Zhou, J. (2019) Microbial functional diversity: From concepts to applications. Ecology and Evolution, 9, 12000-12016.

FAO (2020) FAOSTAT, Food and Agriculture Organization of the United Nations, Rome.

Fowler, D., Coyle, M., Skiba, U., Sutton, M.A., Cape, J.N., Reis, S., Sheppard, L.J., Jenkins, A., Grizzetti, B., Galloway, J.N., Vitousek, P., Leach, A., Bouwman, A.F., Butterbach-Bahl, K., Dentener, F., Stevenson, D., Amann, M. \& Voss, M. (2013) The global nitrogen cycle in the twenty-first century. Phil. Trans. R. Soc. B, 368, 20130164.

Ge, Y., Zhang, J., Zhang, L., Yang, M. \& He, J. (2008) Long-term fertilization regimes affect bacterial community structure and diversity of an agricultural soil in northern China. Journal of Soils and Sediments, 8, 43-50.

Gou, M., Hu, H.-W., Zhang, Y.-J., Wang, J.-T., Hayden, H., Tang, Y.-Q. \& He, J.-Z. (2018) Aerobic composting reduces antibiotic resistance genes in cattle manure and the resistome dissemination in agricultural soils. Science of The Total Environment, 612, 1300-1310.

Gu, Y., Zhang, X., Tu, S. \& Lindström, K. (2009) Soil microbial biomass, crop yields, and bacterial community structure as affected by long-term fertilizer treatments under wheat-rice cropping. European Journal of Soil Biology, 45, 239-246.

Guanghua, W., Junjie, L., Xiaoning, Q., Jian, J., Yang, W. \& Xiaobing, L. (2008) Effects of fertilization on bacterial community structure and function in a black soil of Dehui region estimated by Biolog and PCR-DGGE methods. Acta Ecologica Sinica, 28, 220-226.

Hamm, A.C., Tenuta, M., Krause, D.O., Ominski, K.H., Tkachuk, V.L. \& Flaten, D.N. (2016) Bacterial communities of an agricultural soil amended with solid pig and dairy manures, and urea fertilizer. Applied Soil Ecology, 103, 61-71.

Han, S., Zeng, L., Luo, X., Xiong, X., Wen, S., Wang, B., Chen, W. \& Huang, Q. (2018) Shifts in Nitrobacter- and Nitrospira-like nitrite-oxidizing bacterial communities under long-term fertilization practices. Soil Biology and Biochemistry, 124, 118-125.

Hartmann, M., Frey, B., Mayer, J., Mäder, P. \& Widmer, F. (2015) Distinct soil microbial diversity under long-term organic and conventional farming. The ISME Journal, 9, 1177-1194.

Hedges, L.V., Gurevitch, J. \& Curtis, P.S. (1999) The Meta-Analysis of Response Ratios in Experimental Ecology. Ecology, 80, 1150-1156. 
bioRxiv preprint doi: https://doi.org/10.1101/2020.10.04.325373; this version posted October 8,2020 . The copyright holder for this preprint (which was not certified by peer review) is the author/funder, who has granted bioRxiv a license to display the preprint in perpetuity. It is made available under aCC-BY-NC-ND 4.0 International license.

Fertilizer effects on soil microbial diversity

Higgins, J.P.T. \& Thompson, S.G. (2002) Quantifying heterogeneity in a meta-analysis. Statistics in Medicine, 21, 1539-1558.

Hijbeek, R., van Ittersum, M.K., ten Berge, H.F.M., Gort, G., Spiegel, H. \& Whitmore, A.P. (2017) Do organic inputs matter - a meta-analysis of additional yield effects for arable crops in Europe. Plant and Soil, 411, 293-303.

Howe, A.C., Jansson, J.K., Malfatti, S.A., Tringe, S.G., Tiedje, J.M. \& Brown, C.T. (2014) Tackling soil diversity with the assembly of large, complex metagenomes. Proceedings of the National Academy of Sciences, 111, 4904-4909.

Hu, T., Sørensen, P., Wahlström, E.M., Chirinda, N., Sharif, B., Li, X. \& Olesen, J.E. (2018a) Root biomass in cereals, catch crops and weeds can be reliably estimated without considering aboveground biomass. Agriculture, Ecosystems \& Environment, 251, 141-148.

Hu, X., Liu, J., Wei, D., Zhu, P., Cui, X., Zhou, B., Chen, X., Jin, J., Liu, X. \& Wang, G. (2018b) Soil Bacterial Communities Under Different Long-Term Fertilization Regimes in Three Locations Across the Black Soil Region of Northeast China. Pedosphere, 28, 751-763.

Ji, L., Wu, Z., You, Z., Yi, X., Ni, K., Guo, S. \& Ruan, J. (2018) Effects of organic substitution for synthetic $\mathrm{N}$ fertilizer on soil bacterial diversity and community composition: A 10-year field trial in a tea plantation. Agriculture, Ecosystems \& Environment, 268, 124-132.

Kamaa, M., Mburu, H., Blanchart, E., Chibole, L., Chotte, J.-L., Kibunja, C. \& Lesueur, D. (2011) Effects of organic and inorganic fertilization on soil bacterial and fungal microbial diversity in the Kabete long-term trial, Kenya. Biology and Fertility of Soils, 47, 315-321.

Kibblewhite, M.G., Ritz, K. \& Swift, M.J. (2008) Soil health in agricultural systems. Philosophical Transactions of the Royal Society B: Biological Sciences, 363, 685-701.

Kumar, U., Kumar Nayak, A., Shahid, M., Gupta, V.V.S.R., Panneerselvam, P., Mohanty, S., Kaviraj, M., Kumar, A., Chatterjee, D., Lal, B., Gautam, P., Tripathi, R. \& Panda, B.B. (2018) Continuous application of inorganic and organic fertilizers over 47 years in paddy soil alters the bacterial community structure and its influence on rice production. Agriculture, Ecosystems \& Environment, 262, 65-75.

Kumar, U., Shahid, M., Tripathi, R., Mohanty, S., Kumar, A., Bhattacharyya, P., Lal, B., Gautam, P., Raja, R., Panda, B.B., Jambhulkar, N.N., Shukla, A.K. \& Nayak, A.K. (2017) Variation of functional diversity of soil microbial community in sub-humid tropical rice-rice cropping system under long-term organic and inorganic fertilization. Ecological Indicators, 73, 536543.

Larkin, A.A. \& Martiny, A.C. (2017) Microdiversity shapes the traits, niche space, and biogeography of microbial taxa. Environmental Microbiology Reports, 9, 55-70.

Lehmann, J., Solomon, D., Kinyangi, J., Dathe, L., Wirick, S. \& Jacobsen, C. (2008) Spatial complexity of soil organic matter forms at nanometre scales. Nature Geoscience, 1, 238-242.

Lemanceau, P., Maron, P.-A., Mazurier, S., Mougel, C., Pivato, B., Plassart, P., Ranjard, L., Revellin, C., Tardy, V. \& Wipf, D. (2015) Understanding and managing soil biodiversity: a major challenge in agroecology. Agronomy for Sustainable Development, 35, 67-81.

Levi-Minzi, R., Riffaldi, R. \& Saviozzi, A. (1986) Organic matter and nutrients in fresh and mature farmyard manure. Agricultural Wastes, 16, 225-236.

Li, J., Cooper, J.M., Lin, Z., Li, Y., Yang, X. \& Zhao, B. (2015) Soil microbial community structure and function are significantly affected by long-term organic and mineral fertilization regimes in the North China Plain. Applied Soil Ecology, 96, 75-87.

Liu, W., Wang, Q., Wang, B., Wang, X., Franks, A.E., Teng, Y., Li, Z. \& Luo, Y. (2015) Changes in the abundance and structure of bacterial communities under long-term fertilization treatments in a peanut monocropping system. Plant and Soil, 395, 415-427.

Liu, W., Zhang, Y., Jiang, S., Murray, P.J., Liao, L., Li, X. \& Zhang, J. (2019) Spatiotemporal differences in the arbuscular mycorrhizal fungi communities in soil and roots in response to long-term organic compost inputs in an intensive agricultural cropping system on the North China Plain. Journal of Soils and Sediments, 19, 2520-2533.

Lloyd, K.G., Steen, A.D., Ladau, J., Yin, J. \& Crosby, L. (2018) Phylogenetically Novel Uncultured Microbial Cells Dominate Earth Microbiomes. mSystems, 3. 
bioRxiv preprint doi: https://doi.org/10.1101/2020.10.04.325373; this version posted October 8,2020 . The copyright holder for this preprint (which was not certified by peer review) is the author/funder, who has granted bioRxiv a license to display the preprint in perpetuity. It is made available under aCC-BY-NC-ND 4.0 International license.

Fertilizer effects on soil microbial diversity

Lori, M., Symnaczik, S., Mäder, P., Deyn, G.D. \& Gattinger, A. (2017) Organic farming enhances soil microbial abundance and activity-A meta-analysis and meta-regression. PLOS ONE, 12, e0180442.

Mahanta, D., Bhattacharyya, R., Mishra, P.K., Gopinath, K.A., Channakeshavaih, C., Krishnan, J., Raja, A., Tuti, M.D., Varghese, E., Pandey, B.M., Bisht, J.K. \& Bhatt, J.C. (2017) Influence of a six-year organic and inorganic fertilization on the diversity of the soil culturable microrgansims in the Indian mid-Himalayas. Applied Soil Ecology, 120, 229-238.

Maron, P.-A., Sarr, A., Kaisermann, A., Lévêque, J., Mathieu, O., Guigue, J., Karimi, B., Bernard, L., Dequiedt, S., Terrat, S., Chabbi, A. \& Ranjard, L. (2018) High Microbial Diversity Promotes Soil Ecosystem Functioning. Appl. Environ. Microbiol., 84, e02738-17.

Mazzola, M. (2004) Assessment and Management of Soil Microbial Community Structure for Disease Suppression. Annual Review of Phytopathology, 42, 35-59.

McDaniel, M.D., Tiemann, L.K. \& Grandy, A.S. (2014) Does agricultural crop diversity enhance soil microbial biomass and organic matter dynamics? A meta-analysis. Ecological Applications.

Meng, Q., Yang, W., Men, M., Bello, A., Xu, X., Xu, B., Deng, L., Jiang, X., Sheng, S., Wu, X., Han, Y. \& Zhu, H. (2019) Microbial Community Succession and Response to Environmental Variables During Cow Manure and Corn Straw Composting. Frontiers in Microbiology, 10.

Mensah, S., Veldtman, R., Assogbadjo, A.E., Kakaï, R.G. \& Seifert, T. (2016) Tree species diversity promotes aboveground carbon storage through functional diversity and functional dominance. Ecology and Evolution, 6, 7546-7557.

Morelli, F., Benedetti, Y., Perna, P. \& Santolini, R. (2018) Associations among taxonomic diversity, functional diversity and evolutionary distinctiveness vary among environments. Ecological Indicators, 88, 8-16.

Nautiyal, C.S., Chauhan, P.S. \& Bhatia, C.R. (2010) Changes in soil physico-chemical properties and microbial functional diversity due to 14 years of conversion of grassland to organic agriculture in semi-arid agroecosystem. Soil and Tillage Research, 109, 55-60.

Page, S.E. (2011) Diversity and Complexity, Princeton University Press, Princeton.

Philippot, L., Spor, A., Hénault, C., Bru, D., Bizouard, F., Jones, C.M., Sarr, A. \& Maron, P.-A. (2013) Loss in microbial diversity affects nitrogen cycling in soil. The ISME Journal, 7, 1609-1619.

de Ponti, T., Rijk, B. \& van Ittersum, M.K. (2012) The crop yield gap between organic and conventional agriculture. Agricultural Systems, 108, 1-9.

Qiu, S.-L., Wang, L.-M., Huang, D.-F. \& Lin, X.-J. (2014) Effects of fertilization regimes on tea yields, soil fertility, and soil microbial diversity. Chilean journal of agricultural research, 74, 333339.

Reganold, J.P. \& Wachter, J.M. (2016) Organic agriculture in the twenty-first century. Nature Plants, $2,1-8$.

Ricklefs, R.E. \& Schluter, D. eds. (1994) Species Diversity in Ecological Communities, University of Chicago Press, Chicago.

Rillig, M.C., Wright, S.F. \& Eviner, V.T. (2002) The role of arbuscular mycorrhizal fungi and glomalin in soil aggregation: comparing effects of five plant species. Plant and Soil, 238, 325-333.

Ros, M., Klammer, S., Knapp, B., Aichberger, K. \& Insam, H. (2006) Long-term effects of compost amendment of soil on functional and structural diversity and microbial activity. Soil Use and Management, 22, 209-218.

Rudd, M.A., Beazley, K.F., Cooke, S.J., Fleishman, E., Lane, D.E., Mascia, M.B., Roth, R., Tabor, G., Bakker, J.A., Bellefontaine, T., Berteaux, D., Cantin, B., Chaulk, K.G., Cunningham, K., Dobell, R., Fast, E., Ferrara, N., Findlay, C.S., Hallstrom, L.K., Hammond, T., Hermanutz, L., Hutchings, J.A., Lindsay, K.E., Marta, T.J., Nguyen, V.M., Northey, G., Prior, K., RamirezSanchez, S., Rice, J., Sleep, D.J.H., Szabo, N.D., Trottier, G., Toussaint, J.-P. \& Veilleux, J.-P. (2011) Generation of Priority Research Questions to Inform Conservation Policy and Management at a National Level. Conservation Biology, 25, 476-484.

Sahu, N., Vasu, D., Sahu, A., Lal, N. \& Singh, S.K. (2017) Strength of microbes in nutrient cycling: A key to soil health. Agriculturally Important Microbes for Sustainable Agriculture, .

Sánchez-Bayo, F. \& Wyckhuys, K.A.G. (2019) Worldwide decline of the entomofauna: A review of its drivers. Biological Conservation, 232, 8-27. 
bioRxiv preprint doi: https://doi.org/10.1101/2020.10.04.325373; this version posted October 8,2020 . The copyright holder for this preprint (which was not certified by peer review) is the author/funder, who has granted bioRxiv a license to display the preprint in perpetuity. It is made available under aCC-BY-NC-ND 4.0 International license.

Fertilizer effects on soil microbial diversity

Schrama, M., de Haan, J.J., Kroonen, M., Verstegen, H. \& Van der Putten, W.H. (2018) Crop yield gap and stability in organic and conventional farming systems. Agriculture, Ecosystems and Environment.

Sharma, M. \& Reynnells, R. (2016) Importance of Soil Amendments: Survival of Bacterial Pathogens in Manure and Compost Used as Organic Fertilizers. Microbiology Spectrum, 4, PFS-00102015.

Sun, H.Y., Deng, S.P. \& Raun, W.R. (2004) Bacterial Community Structure and Diversity in a CenturyOld Manure-Treated Agroecosystem. Applied and Environmental Microbiology, 70, 58685874.

Sutherland, W.J., Armstrong-Brown, S., Armsworth, P.R., Tom, B., Brickland, J., Campbell, C.D., Chamberlain, D.E., Cooke, A.I., Dulvy, N.K., Dusic, N.R., Fitton, M., Freckleton, R.P., Godfray, H.C.J., Grout, N., Harvey, H.J., Hedley, C., Hopkins, J.J., Kift, N.B., Kirby, J., Kunin, W.E., Macdonald, D.W., Marker, B., Naura, M., Neale, A.R., Oliver, T., Osborn, D., Pullin, A.S., Shardlow, M.E.A., Showler, D.A., Smith, P.L., Smithers, R.J., Solandt, J.-L., Spencer, J., Spray, C.J., Thomas, C.D., Thompson, J., Webb, S.E., Yalden, D.W. \& Watkinson, A.R. (2006) The identification of 100 ecological questions of high policy relevance in the UK. Journal of Applied Ecology, 43, 617-627.

Thompson, L.R., et al. (2017) A communal catalogue reveals Earth's multiscale microbial diversity. Nature, 551, 457.

Venter, Z.S., Jacobs, K. \& Hawkins, H.J. (2016) The impact of crop rotation on soil microbial diversity: A meta-analysis. Pedobiologia.

Viechtbauer, W. (2010) Conducting Meta-Analyses in R with the metafor Package. Journal of Statistical Software, 36, 1-48.

Vos, M., Wolf, A.B., Jennings, S.J. \& Kowalchuk, G.A. (2013) Micro-scale determinants of bacterial diversity in soil. FEMS Microbiology Reviews, 37, 936-954.

Wang, Q., Jiang, X., Guan, D., Wei, D., Zhao, B., Ma, M., Chen, S., Li, L., Cao, F. \& Li, J. (2018) Long-term fertilization changes bacterial diversity and bacterial communities in the maize rhizosphere of Chinese Mollisols. Applied Soil Ecology, 125, 88-96.

Wei, D., Yang, Q., Zhang, J.-Z., Wang, S., Chen, X.-L., Zhang, X.-L. \& Li, W.-Q. (2008) Bacterial Community Structure and Diversity in a Black Soil as Affected by Long-Term Fertilization*1 *1Project supported by the Heilongjiang Provincial Natural Science Funds for Distinguished Young Scholars, China (No. JC200622), the Heilongjiang Provincial Natural Science Foundation of China (No. C2004-17), and the National "Eleventh Five Years Plan" Key Project on Science and Technology of China (No. 2006BAD25B05). Pedosphere, 18, 582-592.

Wuepper, D., Borrelli, P. \& Finger, R. (2020) Countries and the global rate of soil erosion. Nature Sustainability, 3, 51-55.

Yao, L., Wang, D., Kang, L., Wang, D., Zhang, Y., Hou, X. \& Guo, Y. (2018) Effects of fertilizations on soil bacteria and fungi communities in a degraded arid steppe revealed by high through-put sequencing. PeerJ, 6, e4623.

Zhang, Q., Buyantuev, A., Li, F.Y., Jiang, L., Niu, J., Ding, Y., Kang, S. \& Ma, W. (2017) Functional dominance rather than taxonomic diversity and functional diversity mainly affects community aboveground biomass in the Inner Mongolia grassland. Ecology and Evolution, 7, 1605-1615.

Zhang, X., Davidson, E.A., Mauzerall, D.L., Searchinger, T.D., Dumas, P. \& Shen, Y. (2015) Managing nitrogen for sustainable development. Nature, 528, 51-59.

Zhang, X., Johnston, E.R., Wang, Y., Yu, Q., Tian, D., Wang, Z., Zhang, Y., Gong, D., Luo, C., Liu, W., Yang, J. \& Han, X. (2019) Distinct Drivers of Core and Accessory Components of Soil Microbial Community Functional Diversity under Environmental Changes. mSystems, 4.

Zhong, W., Gu, T., Wang, W., Zhang, B., Lin, X., Huang, Q. \& Shen, W. (2010) The effects of mineral fertilizer and organic manure on soil microbial community and diversity. Plant and Soil, 326, 511-522.

Zhou, Z., Wang, C. \& Luo, Y. (2020) Meta-analysis of the impacts of global change factors on soil microbial diversity and functionality. Nature Communications, 11, 3072. 


\section{TABLES}

565

566

\begin{tabular}{lrrrrrrr}
\hline Comparison & Studies (N) & LRM & LRM $(95 \%$ CI) & $\mathrm{t}$ & $\mathrm{P}$ & Change $(\%)$ & Change 95 \% CI \\
\hline NPK vs. CON & $6(8)$ & $0.026 \pm 0.004$ & $0.016,0.035$ & 6.51 & 0.0003 & 2.6 & $1.7,3.6$ \\
ORG vs. CON & $7(9)$ & $0.066 \pm 0.011$ & $0.041,0.090$ & 6.21 & 0.0003 & 6.8 & $4.2,9.4$ \\
ORG vs. NPK & $7(9)$ & $0.035 \pm 0.012$ & $0.008,0.063$ & 3.00 & 0.0171 & 3.6 & $0.8,6.5$ \\
\hline
\end{tabular}
of the effect size vs. zero. Change (\%) is the effect-size back-transformed to percentage change.

569

Table 1. Summary statistics for meta-analysis of functional diversity $\left(\mathrm{H}_{\text {fun }}\right)$ differences between fertilizer treatments and control. One study (Ros et al., 2006) reported three comparisons, hence a multi-level random model was employed to control for within-study effects. Studies (N) refers to the number of studies and number of comparisons in this estimate. LRM is the log-transformed ratio of means, giving mean $\pm \mathrm{SE}$ and $95 \%$ Confidence Interval. $t$ and $\mathrm{P}$ are a t-test 
Table 2. Summary statistics for meta-analysis of taxonomic diversity differences between fertilizer treatments and control. Statistics as in Table 1.

\begin{tabular}{llrrrrrrr}
\hline Comparison & Class & Studies (N) & LRM & LRM (95\% CI) & $\mathrm{t}$ & P & Change (\%) & Change \% (95 \% CI) \\
\hline NPK vs. CON & All* & $1(1)$ & $-0.042 \pm 0.100$ & $-0.239,0.155$ & -0.42 & 0.67 & -4.1 & $-21.1,16.7$ \\
& Fungi & $6(7)$ & $0.031 \pm 0.020$ & $-0.007,0.069$ & 1.58 & 0.11 & 3.1 & $-0.73,7.5$ \\
& Prokaryotes & $18(23)$ & $-0.006 \pm 0.016$ & $-0.037,0.026$ & -0.35 & 0.73 & -0.5 & $-3.6,2.6$ \\
\hline ORG vs. CON & All* & $1(6)$ & $0.372 \pm 0.065$ & $0.245,0.499$ & 5.76 & $10^{-8}$ & 46.1 & $35.4,57.7$ \\
& Fungi & $6(8)$ & $0.016 \pm 0.022$ & $-0.028,0.059$ & 0.70 & 0.48 & 1.6 & $-2.7,6.1$ \\
& Prokaryotes & $18(23)$ & $0.041 \pm 0.014$ & $0.013,0.069$ & 2.84 & 0.004 & 4.2 & $1.3,7.1$ \\
\hline ORG vs. NPK & All* & $1(6)$ & $0.419 \pm 0.072$ & $0.017,0.072$ & 5.79 & $10^{-8}$ & 52.9 & $40.1,66.8$ \\
& Fungi & $6(8)$ & $-0.055 \pm 0.021$ & $-0.097,-0.013$ & 2.61 & 0.009 & -5.4 & $-9.2,-1.4$ \\
& Prokaryotes & $23(33)$ & $0.045 \pm 0.014$ & $0.017,0.073$ & 3.20 & 0.001 & 4.6 & $1.8,7.5$ \\
\hline
\end{tabular}

*A single study (Mahanta et al., 2017) contributed to this estimate. 


\section{Fertilizer effects on soil microbial diversity}

\section{FIGURES}

a

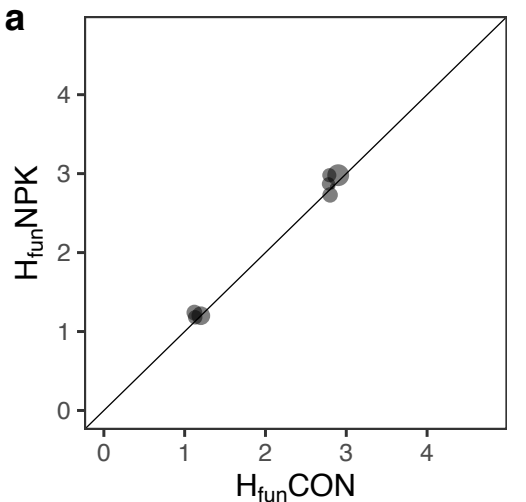

d

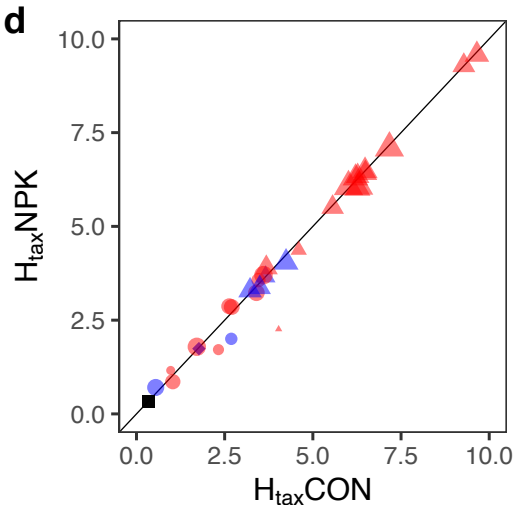

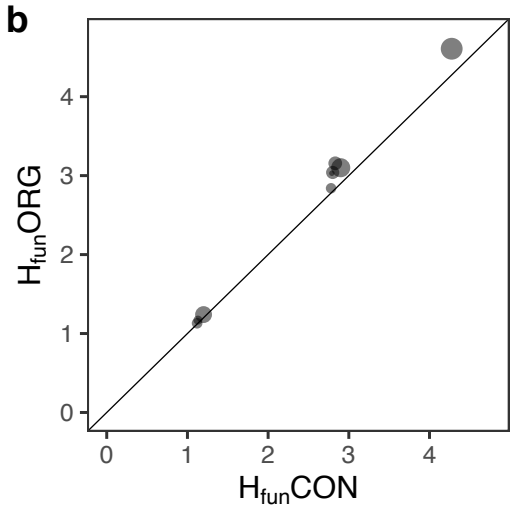

e

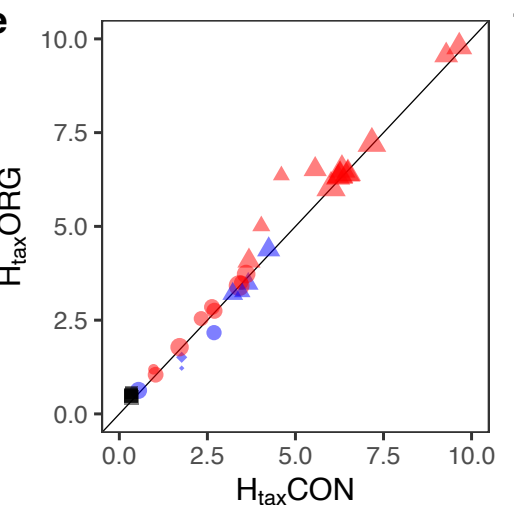

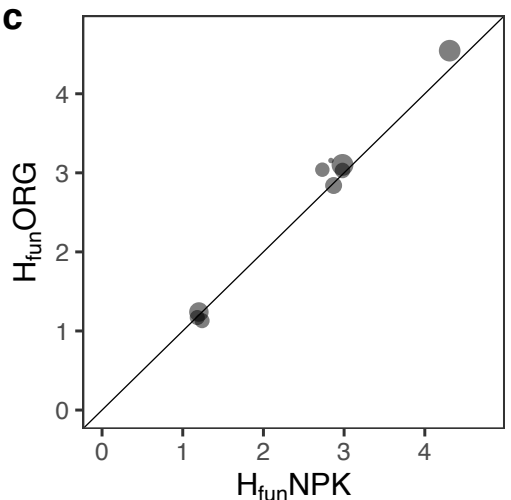

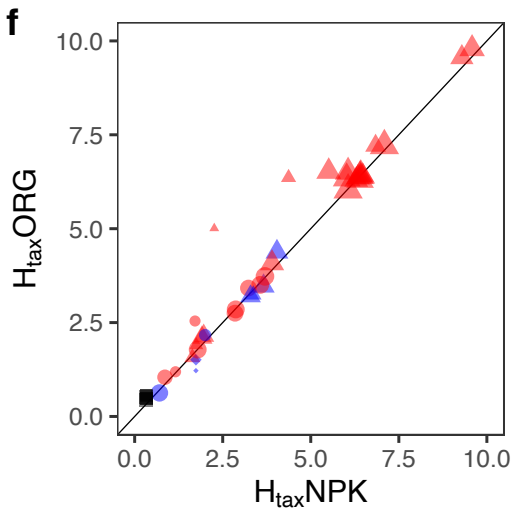

Fig. 1. Comparison of $\mathrm{H}_{\text {fun }}(\mathrm{a}-\mathrm{c})$ and $\mathrm{H}_{\text {tax }}(\mathrm{d}-\mathrm{f})$ in $(\mathrm{a}, \mathrm{d}) \mathrm{NPK}$ vs. CON, (b,e) ORG vs. CON, (c,f) ORG

577 vs. NPK. Points show reported values with size proportional to $\log (1 /$ variance $)$. Results for Fungi are

578 in blue, Bacteria in red. Gel electrophoresis results are circles, sequencing results are triangles, TRFLP are diamonds. The single soil dilution plate assay is shown as black squares. 


\section{Fertilizer effects on soil microbial diversity}

a

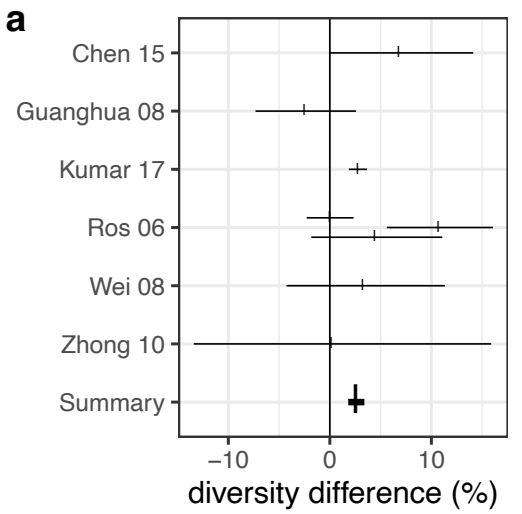

b

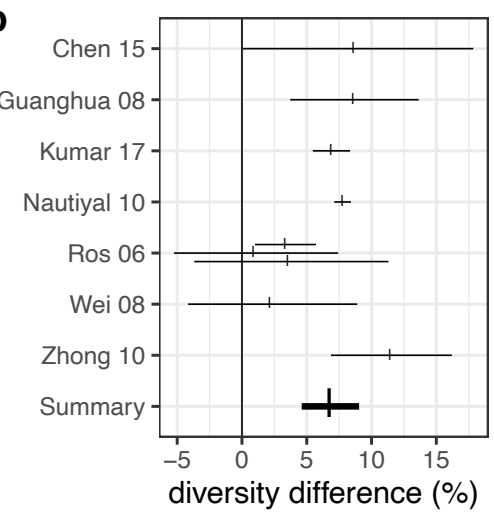

C

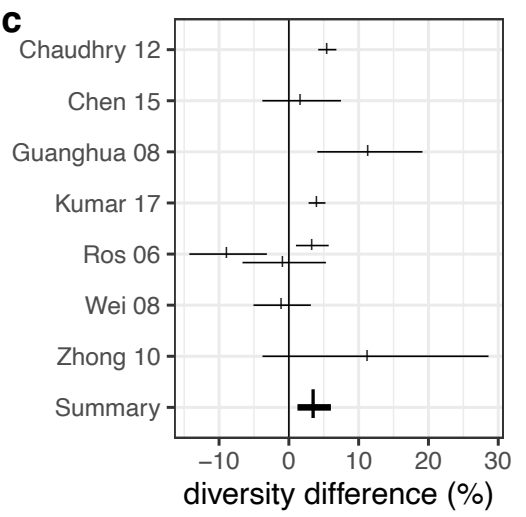

582 Fig. 2. Functional soil diversity differences. a) NPK vs. CON, b) ORG vs. CON, c) ORG vs. NPK.

583 Horizontal bars and ticks show 95\% confidence intervals and means for effect sizes from the log-

584 transformed ratio of means, back-transformed to give percentage differences. Summary estimates are given at the bottom of each plot. Random intercepts were fitted per Study. 
a

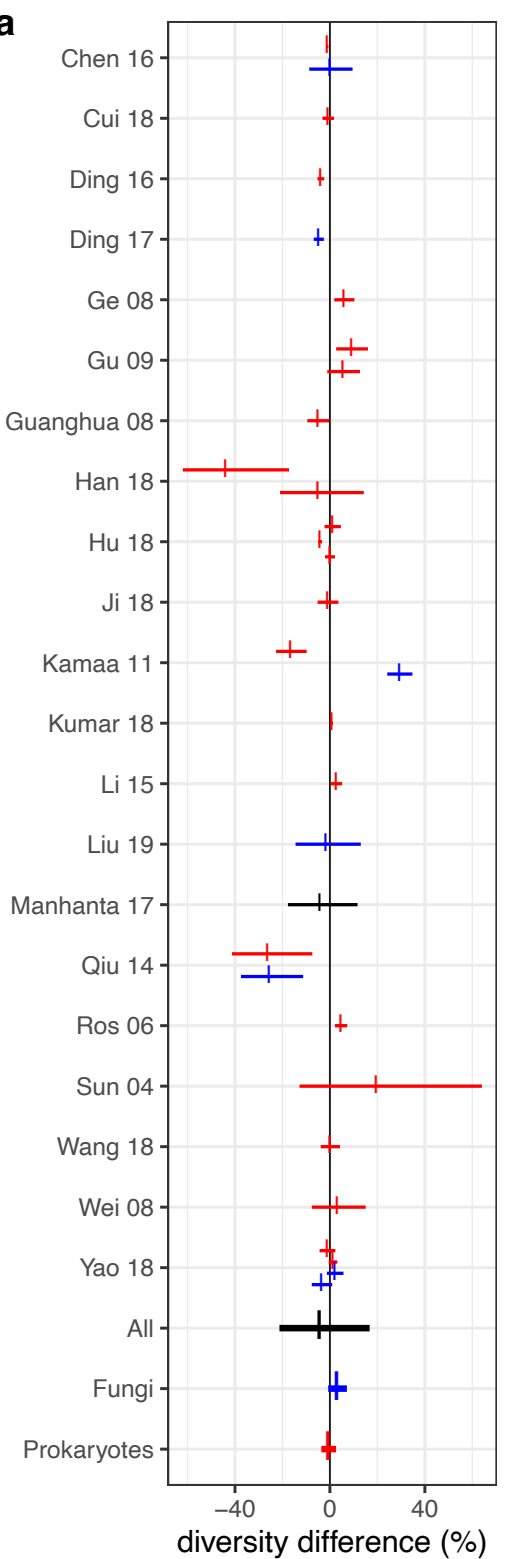

b

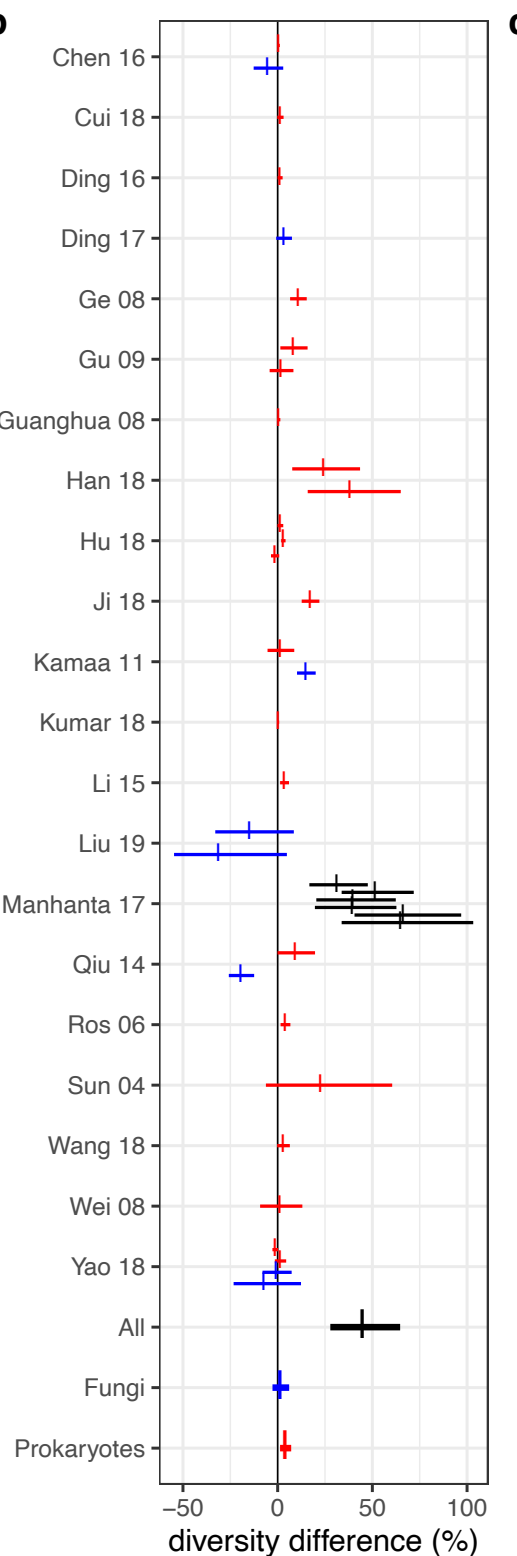

c

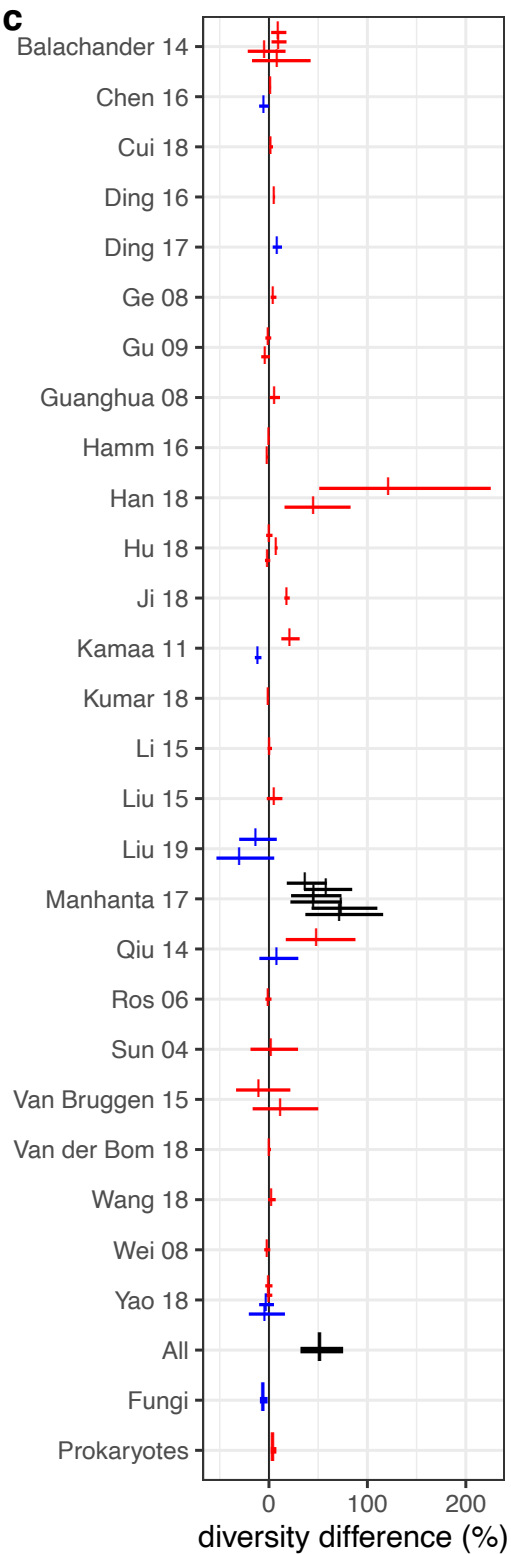

Fig. 3. Taxonomic diversity effect sizes. a) NPK vs. CON, b) ORG vs. CON, c) ORG vs. NPK.

589 Horizontal bars and ticks show 95\% confidence intervals and means for effect sizes from the log-

590 transformed ratio of means, back-transformed to give percentage differences. Summary estimates are

591 given at the bottom of each plot, for All microbes (black), Fungi (blue) and Bacteria (red). Random intercepts were fitted per Study. "All” refers to results of a single study (Mahanta et al., 2017) which used soil dilution plate assays. 
bioRxiv preprint doi: https://doi org/10.1101/2020 10.04 325373; this version posted October 8, 2020. The copyright holder for this preprint (which was not certified by peer review) is the author/funder, who has granted bioRxiv a license to display the preprint in perpetuity. It is made available under aCC-BY-NC-ND 4.0 International license.

Fertilizer effects on soil microbial diversity

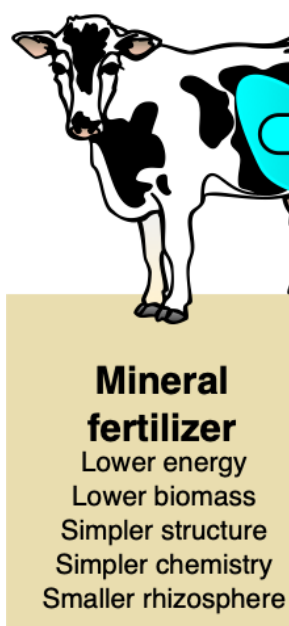

\section{Organic fertilizer}

Fig. 4. Representation of processes influencing organic fertilizer affects on soil microbial diversity. See Discussion for details. 
Fertilizer effects on soil microbial diversity

599

600

601

602

603

604

605

606

607

608

609

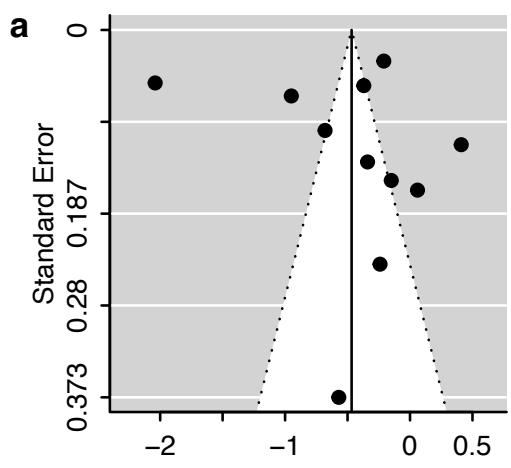

b

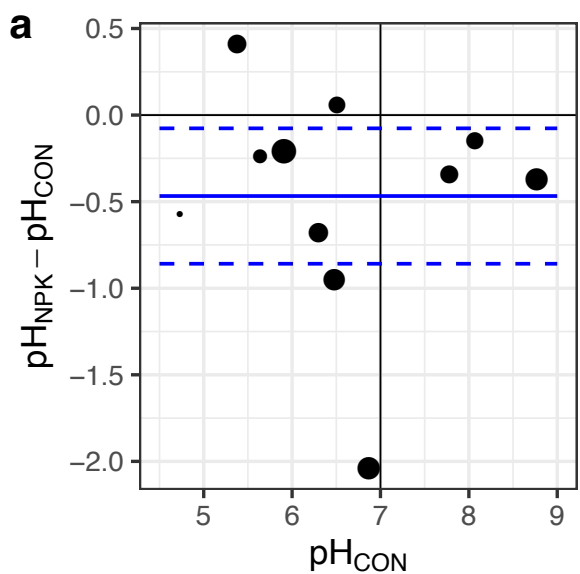
size proportional to $\log (1 /$ variance $)$.

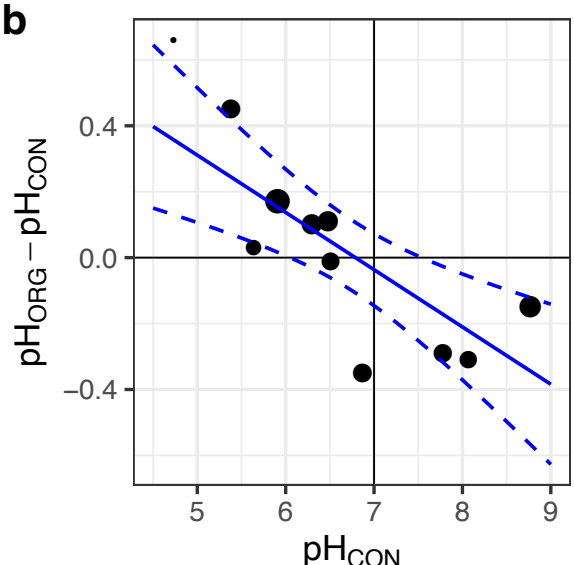

Fig. S1. Effect of fertilization on soil pH. a) Mean difference between NPK and CON vs. mean CON $\mathrm{pH}$. Blue solid and dashed lines show mean difference $(-0.46 \pm 0.20 \mathrm{SE}, \mathrm{Z}=-2.34, \mathrm{p}=0.019)$ and 95 $\%$ CI $(-0.86,-0.08)$ of meta-analysis fit. b) Mean difference between ORG and CON vs. mean CON $\mathrm{pH}$. Blue solid and dashed lines show mean and 95\% CI of meta-regression fit. Slope mean $-0.174 \pm$ $0.050, \mathrm{Z}=-3.47, \mathrm{p}=0.0005,95 \% \mathrm{CI}=-0.272,-0.076$. Points show means from individual studies with

610 Fig. S2. Funnel plots for soil pH meta-analysis. Kendall's $\tau$ and p-values are given for rank correlation

611 tests for funnel plot asymmetry. a) NPK vs. CON ( $\tau=-0.055, p=0.88)$, b) ORG vs. CON $(\tau=-0.018$, $612 \mathrm{p}=1.0)$. 
a

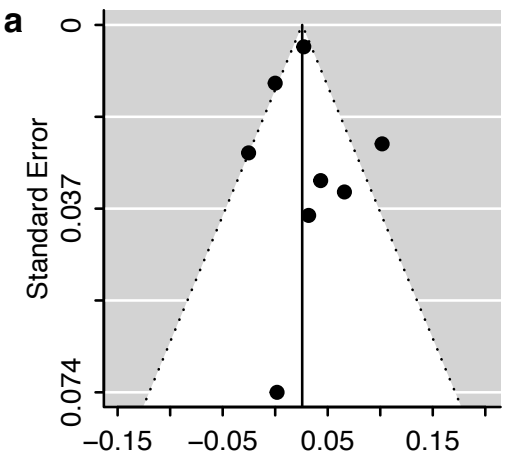

b

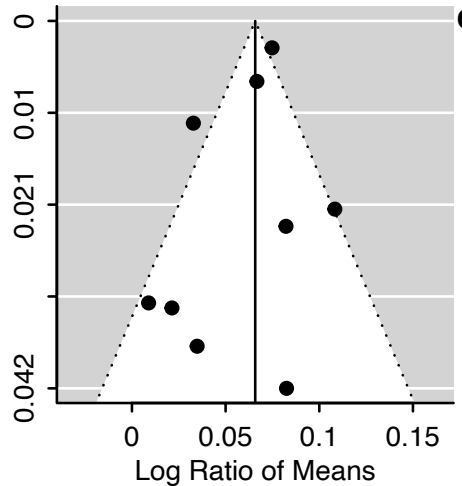

c

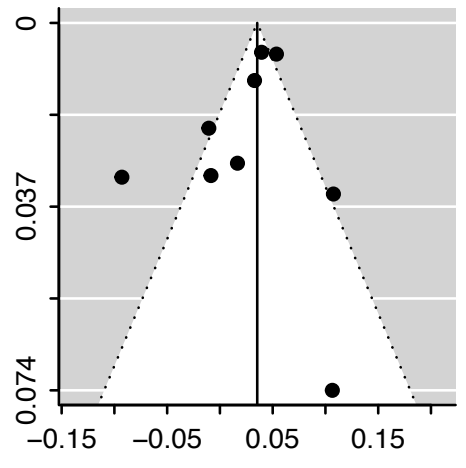

616 Fig. S3. Funnel plots for functional diversity meta-analysis. Kendall's $\tau$ and p-values are given for rank

617 correlation tests for funnel plot asymmetry. a) NPK vs. CON ( $\tau=-0.071, p=0.90)$, b) ORG vs. CON $618(\tau=-0.167, \mathrm{p}=0.61), \mathrm{c})$ ORG vs. NPK $(\tau=-0.167, \mathrm{p}=0.61)$.

619

a

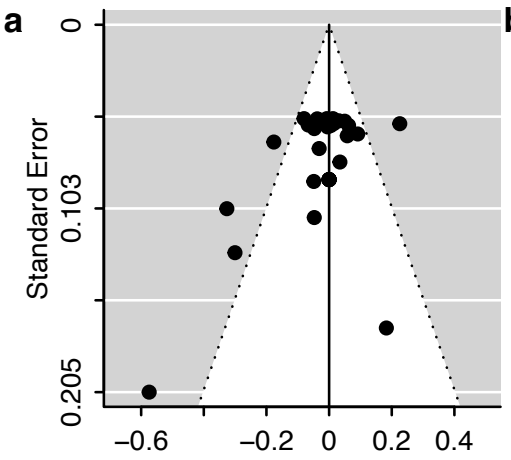

b

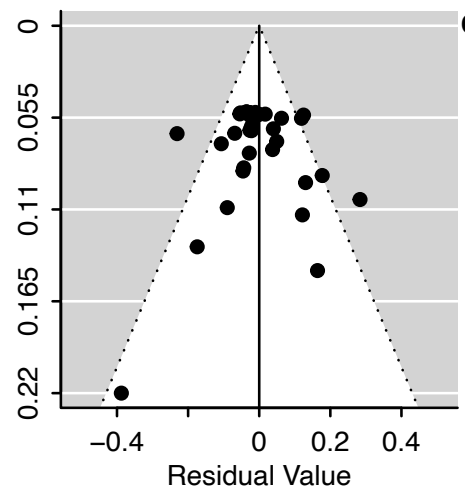

c

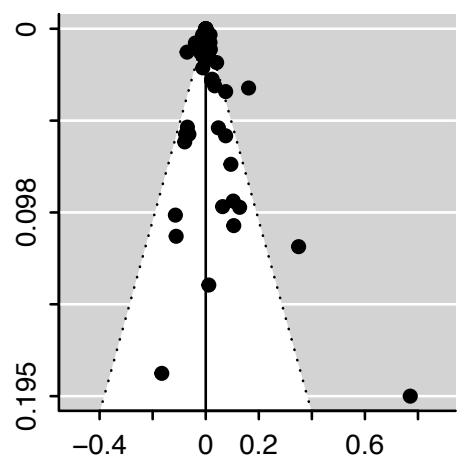

620

621 Fig. S4. Funnel plots for taxonomic diversity meta-analysis. Kendall's $\tau$ and p-values are given for rank correlation tests for funnel plot asymmetry. a) NPK vs. CON $(\tau=-0.123, p=0.34)$, b) ORG vs. CON $(\tau=0.156, p=0.18), c)$ ORG vs. NPK $(\tau=0.149, p=0.14)$. 
bioRxiv preprint doi: https://doi.org/10.1101/2020.10.04.325373; this version posted October 8,2020 . The copyright holder for this preprint (which was not certified by peer review) is the author/funder, who has granted bioRxiv a license to display the preprint in perpetuity. It is made available under aCC-BY-NC-ND 4.0 International license.

Fertilizer effects on soil microbial diversity

626 Table S1. Summary of studies included in the meta-analysis (alphabetical order).

\begin{tabular}{|c|c|c|c|}
\hline Study & Location & Measure & Methodology \\
\hline (Balachandar et al., 2014) & Tamil Nadu, India & Taxonomic & $16 \mathrm{~S}$ seq \\
\hline (Chaudhry et al., 2012) & Maharashtra, India & Functional & Biolog Ecoplate \\
\hline (Chen et al., 2015) & Jiangxi, China & Functional & Biolog Ecoplate \\
\hline (Chen et al., 2016) & Jiangsu, China & Taxonomic & $18 \mathrm{~S}$ seq \\
\hline (Cui et al., 2018) & Hunan, China & Taxonomic & $16 \mathrm{~S}$ seq \\
\hline (Ding et al., 2016) & Heilongjiang, China & Taxonomic & $16 \mathrm{~S}$ seq \\
\hline (Ding et al., 2017) & Heilongjiang, China & Taxonomic & ITS seq \\
\hline (Ge et al., 2008) & Fengqiu, China & Taxonomic & $16 \mathrm{~S}$ seq \\
\hline (Gu et al., 2009) & Sichuan, China & Taxonomic & 16S DGGE \\
\hline (Guanghua et al., 2008) & Jilin, China & $\begin{array}{l}\text { Taxonomic } \\
\text { Functional }\end{array}$ & $\begin{array}{l}\text { 16S DGGE } \\
\text { Biolog Ecoplate }\end{array}$ \\
\hline (Hamm et al & Manitoba, Canada & Taxonomic & $16 \mathrm{~S}$ seq \\
\hline (Han et al., & Hunan, China & Taxonomic & nxr seq \\
\hline (Hu et al., 2018b) & Northeast China & Taxonomic & $16 \mathrm{~S}$ seq \\
\hline (Ji et al., 2018) & Fujian, China & Taxonomic & $16 \mathrm{~S}$ seq \\
\hline (Kamaa et al., 2011) & Kabete, Kenya & Taxonomic & $16 \mathrm{~S}$ and $28 \mathrm{~S}$ DGGE \\
\hline (Kumar et al., 2017) & Odisha, India & Functional & Biolog Ecoplate \\
\hline (Kumar et al., 2018) & Odisha, India & Taxonomic & $16 \mathrm{~S}$ seq \\
\hline (Li et al., 2015) & Shandong, China & Taxonomic & 16S DGGE \\
\hline (Liu et al., 2015) & Jiangxi, China & Taxonomic & $16 \mathrm{~S}$ seq \\
\hline (Liu et al., 2019) & Hebei, China & Taxonomic & TRFLP \\
\hline (Mahanta et al., 2017) & Uttarakhand, India & Taxonomic & Soil dilution plate \\
\hline (Nautiyal et al., 2010) & Maharashtra, India & Functional & Biolog Ecoplate \\
\hline (Qiu et al., 2014) & Fujian, China & Taxonomic & $16 \mathrm{~S}$ and $18 \mathrm{~S}$ TGGE \\
\hline (Ros et al., 2006) & Linz, Austria & $\begin{array}{l}\text { Taxonomic } \\
\text { Functional }\end{array}$ & $\begin{array}{l}\text { 16S PGGE } \\
\text { Biolog Ecoplate }\end{array}$ \\
\hline (Sun et al., 2004) & Okla & Taxonomic & 16S DGGE \\
\hline (van Bruggen et al., 2015) & Netherlands & Taxonomic & 16S DGGE \\
\hline (van der Bom et al., 2018) & Denmark & Taxonomic & $16 \mathrm{~S}$ seq \\
\hline (Wang et al., 2018) & Heilongjiang, China & Taxonomic & $16 \mathrm{~S}$ seq \\
\hline (Wei et al., 2008) & Heilongjiang, China & $\begin{array}{l}\text { Taxonomic } \\
\text { Functional }\end{array}$ & $\begin{array}{l}\text { 16S DGGE } \\
\text { Biolog Ecoplate }\end{array}$ \\
\hline$(\mathrm{Ya}$ & a, China & Taxonomic & $16 \mathrm{~S}$ and $18 \mathrm{~S}$ seq \\
\hline (Zhong et al., 2010) & Jiangxi, China & Functional & Biolog Ecoplate \\
\hline
\end{tabular}


bioRxiv preprint doi: https://doi.org/10.1101/2020.10.04.325373; this version posted October 8, 2020. The copyright holder for this preprint (which was not certified by peer review) is the author/funder, who has granted bioRxiv a license to display the preprint in perpetuity. It is made available under aCC-BY-NC-ND 4.0 International license.

628 Table S2. Meta-analysis diagnostics.

\begin{tabular}{|c|c|c|c|c|}
\hline Test & $\mathrm{I}^{2}(\%)$ & $\mathrm{Q}$ & $\mathrm{df}$ & $\bar{P}$ \\
\hline $\mathrm{H}_{\text {fun }} \mathrm{NPK}$ vs. CON & 75.8 & 20.6 & 7 & 0.0044 \\
\hline $\mathrm{H}_{\text {fun }}$ ORG vs. CON & 77.8 & 23.2 & 8 & 0.0031 \\
\hline $\mathrm{H}_{\text {fun }} \mathrm{ORG}$ vs. NPK & 76.6 & 36.9 & 8 & $<0.0001$ \\
\hline $\mathrm{H}_{\mathrm{tax}} \mathrm{NPK}$ vs. CON & 97.0 & 406.6 & 33 & $<0.0001$ \\
\hline $\mathrm{H}_{\mathrm{tax}} \mathrm{ORG}$ vs. CON & 97.0 & 231.2 & 34 & $<0.0001$ \\
\hline $\mathrm{H}_{\text {tax }}$ ORG vs. NPK & 97.6 & 601.4 & 44 & $<0.0001$ \\
\hline $\mathrm{pH}_{\mathrm{NPK}}-\mathrm{pH}_{\mathrm{CON}}$ vs. $\mathrm{pH}_{\mathrm{CON}}$ & 98.5 & 1017.5 & 10 & $<0.0001$ \\
\hline pH $H_{\text {ORG }}-\mathrm{pH}_{\mathrm{CON}}$ vs. $\mathrm{pH}_{\mathrm{CON}}$ & 69.6 & 23.1 & 9 & 0.0059 \\
\hline
\end{tabular}

629 